\title{
First description of the male of Platocoelotes uenoi (Yamaguchi \& Yaginuma 1971), n. comb. and a new record of Draconarius coreanus (Paik \& Yaginuma 1969) (Araneae: Coelotidae) from Kyushu, Japan
}

\author{
Ken-ichi Okumura
}

\author{
Nagasaki Prefectural Goto-minami Senior High School, \\ Kishiku-cho, Kawara 3487, Goto-shi, Nagasaki, 853-0702, Japan \\ E-mail: coelotes@orchid.plala.or.jp
}

\begin{abstract}
The male of Platocoelotes uenoi (Yamaguchi \& Yaginuma 1971), n. comb. is described for the first time on the basis of specimens collected from Fukue Island, Kyushu, Japan. The species is transferred from the genus Coelotes. Draconarius coreanus (Paik \& Yaginuma 1969) is recognized for the first time from Japan on the basis of a female specimen collected from Tsushima Island. The spider was first recorded as Coelotes sp. from the same island by Yaginuma et al. (1976).
\end{abstract}

Key words - Araneae, Coelotidae, Platocoelotes, Draconarius, first description, new combination, new record

\section{Introduction}

In Japan, about one hundred species of coelotid spiders have been described up to the present (Okumura et al., 2009), but some species were described using only a single sex. Coelotes uenoi Yamaguchi \& Yaginuma 1971, described from Fukue Island, Kyushu, Japan, is known only by female specimens up to the present. I surveyed Fukue Islamd in 2008, and was able to collect some male specimens of the species. It has been treated as a member of the genus Coelotes, but after a careful examination of the genital organs of both sexes, I concluded that the species should be transferred to the genus Platocoelotes Wang 2002. This genus is characterized by the presence of a conductor posterior apophysis and absence of a median apophysis in male palp, and by the presence of an anterior epigynal cavity and absence of epigynal teeth in female genitalia (Wang, 2002). Genital organs of both sexes of the species conform to the above characteristics.

The genus Draconarius including about one hundred fifty species is the main coelotid group in the East Asia, but no species has been recorded from Japan (Platnick, 2009; Okumura et al., 2009). Draconarius coreanus (Paik \& Yaginuma 1969) described from Jeju-do Island, Korea is characterized by having a pale colored body and legs, two retromarginal teeth on chelicera, and widely separated small epigynal teeth and convoluted spermathecae in the female genitalia. I surveyed Tsushima Island in December 2008, and collected a female specimen of this species.

In this paper, I transfer Coelotes uenoi Yamaguchi \& Yaginuma 1971 to the genus Platocoelotes Wang 2002, and describe the male of the species for the first time. Furthermore I report on a record of Draconarius coreanus (Paik \& Yaginuma 1969) from Japan.

The abbreviations used in this paper are as follows: ALE, anterior lateral eye; AME, anterior median eye; MOA, median ocular area; PLE, posterior lateral eye; PME, posterior median eye.

The voucher specimens used for this study are deposited in the collection of the Department of Zoology, National Museum of Nature and Science, Tokyo.

I wish to express my sincere thanks to Dr. Hirotsugu Ono, Tokyo, for reading the manuscript and for helpful suggestions.

Platocoelotes uenoi (Yamaguchi \& Yaginuma 1971), n. comb.

(Figs. 1-4)

Coelotes uenoi Yamaguchi \& Yaginuma, 1971, pp. 178-179, figs. 8-9; Yaginuma, 1986, p. 151, fig. 82; Okumura et al., 2009, p. 197, figs. $353-354$.

Specimens examined. All the specimens were collected from Fukue Is., Goto Islands, Nagasaki Pref., Kyushu, Japan, and by K. Okumura. Sakishirazu-no-i-ana Cave, Tomie-cho, 2우, April 19, 2008; 10 1 juvenile, October 27, 2008; Kishiku-cho, $10^{\Uparrow}$, October 25, 2008; $20^{\Uparrow} 1$ 우, November 15, 2008.

Description (one male from the above specimens). Measurements in mm: Total length 7.44; carapace 3.75 long, 3.09 wide; abdomen 3.69 long, 2.03 wide; sternum 
1.86 long, 1.59 wide. Eye sizes: AME 0.08, ALE 0.12, PME 0.11, PLE 0.10. Distances between eyes: AME-AME 0.02, AME-ALE 0.02, PME-PME 0.07, PME-PLE 0.08, AMEPME 0.05, ALE-PLE 0.03. MOA: anterior width 0.18, posterior width 0.29 , length 0.20 . Leg measurements as shown in Table 1.
Chericera: retromargin with three teeth.

Male palp (Figs. 1, 2): embolus long, conductor stout and slightly curved, conductor posterior apophysis swordshaped and pointing to the base of cymbium obliquely, both patellar apophysis and lateral tibial one small.

Coloration: carapace yellowish gray, dorsum of abdomen
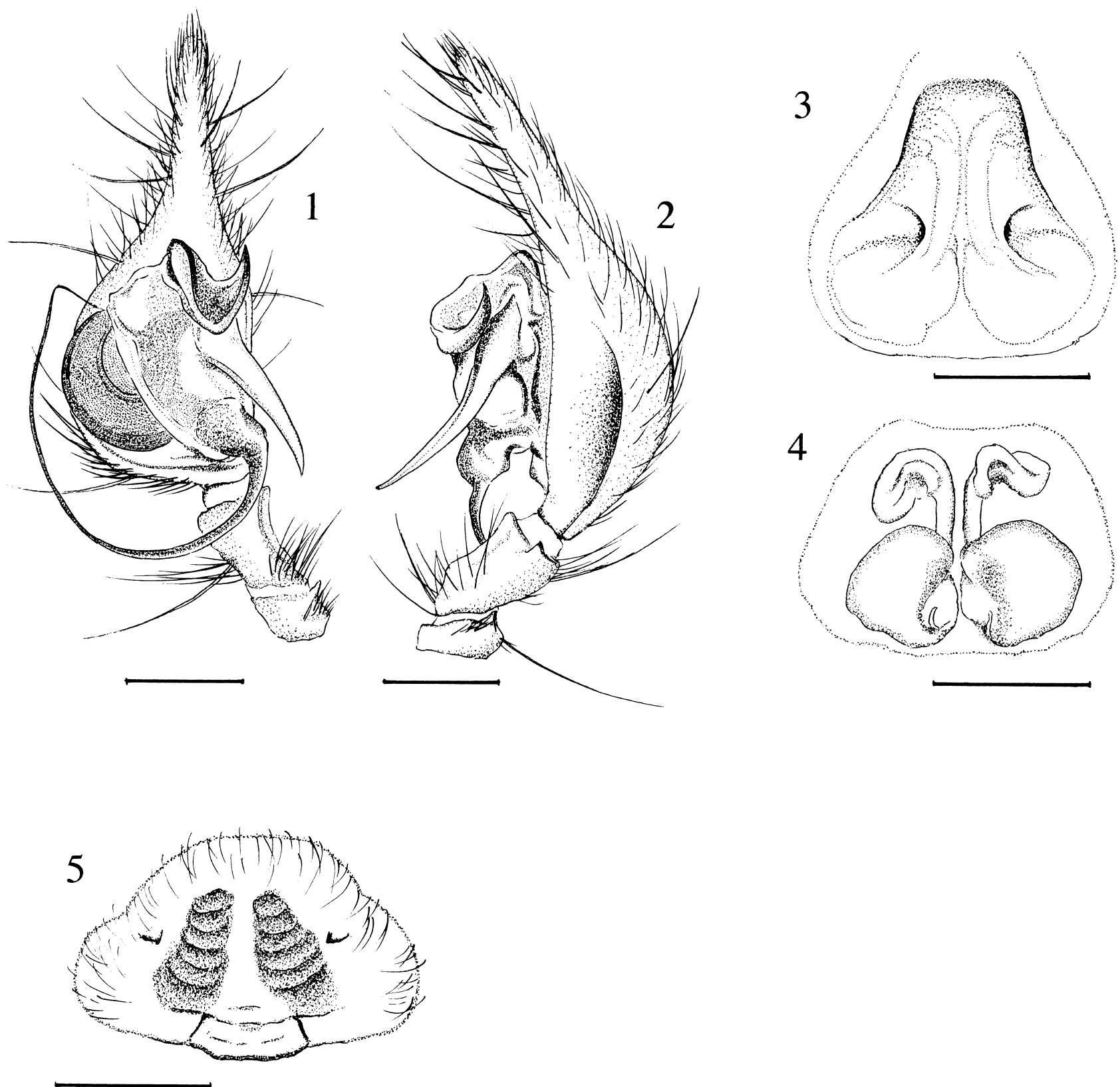

Fig. 1-5. 1-4, Platocoelotes uenoi (Yamaguchi \& Yaginuma 1971); 5, Draconarius coreanus (Paik \& Yaginuma 1969). — 1, Male palp, ventral view; 2 , same, retrolateral view; 3, 5, epigynum; 4, internal female genitalia. Scales: $0.5 \mathrm{~mm}$.

Table 1. Leg measurements of Platocoelotes uenoi (in $\mathrm{mm}$ ).

\begin{tabular}{cccccc}
\hline Legs & Femur & Patella and tibia & Metatarsus & Tarsus & Total \\
\hline I & 4.28 & 5.34 & 4.19 & 2.56 & 16.37 \\
II & 4.09 & 4.75 & 3.88 & 2.41 & 15.13 \\
III & 3.81 & 4.41 & 4.00 & 1.91 & 14.13 \\
IV & 4.75 & 5.63 & 5.72 & 2.69 & 18.79 \\
\hline
\end{tabular}


Table 2. Leg measurements of Draconarius coreanus (in mm).

\begin{tabular}{cccccr}
\hline Legs & Femur & Patella and tibia & Metatarsus & Tarsus & Total \\
\hline I & 3.06 & 3.97 & 2.63 & 1.75 & 11.41 \\
II & 2.78 & 3.47 & 2.56 & 1.41 & 10.22 \\
III & 2.47 & 3.03 & 2.50 & 1.31 & 9.31 \\
IV & 3.50 & 4.31 & 3.97 & 1.81 & 13.59 \\
\hline
\end{tabular}

gray with indistinct chevrons, sternum yellowish brown, chelicerae and maxillae brown, labium yellowish brown, legs yellowish gray without ring flecks.

Remark. Platocoelotes uenoi has hitherto been collected only from lava caves, but I collected some specimens also from under stones in the forest.

\section{Draconarius coreanus (Paik \& Yaginuma 1969)} (Fig. 5)

Coelotes coreanus Paik \& Yaginuma, 1969, p. 837, figs. 62-64; Namkung, 2002, p. 389, fig. 28.

Coelotes sp.: Yaginuma et al., 1976, p. 828, fig. 5.

Draconarius coreanus: Wang, 2002, p. 67, 2003, p. 526, fig. 22; Kim \& Lee, 2007, pp. 114-119, figs. 1-19.

Specimen examined. Mt. Mitake, $380 \mathrm{~m}$ alt., Tsushima Is., Nagasaki Pref., Kyushu, Japan, 1우, December 27, 2008, K. Okumura leg.

Description (above female specimen). Measurements in mm: Total length 7.19; carapace 3.56 long, 2.16 wide; abdomen 3.63 long, 2.19 wide; sternum 1.81 long, 1.56 wide. Eye sizes: AME 0.06, ALE 0.13, PME 0.10, PLE 0.15. Distances between eyes: AME-AME 0.08, AME-ALE 0.08, PME-PME 0.13, PME-PLE 0.16, AME-PME 0.09, ALEPLE 0.08. MOA: anterior width 0.20 , posterior width 0.33 , length 0.25. Leg measurements as shown in Table 2.

Chericera: retromargin with two teeth.

Epigynum (Fig. 5): epigynal plate trapeziform, small epigynal teeth separated from each other, situated in the middle of epigynum, atrium rectangular situated posterior portion of epigynum.

Coloration: carapace yellowish brown (anterior region darker), dorsum of abdomen yellowish gray, sternum yellowish brown, chelicerae, maxillae and labium brown, legs yellowish brown without ring flecks.

Remarks. Draconarius coreanus has been collected only from Seong Lava Cave, Jeju-do Is., Korea up to the present (Kim \& Lee 2007), but in my survey, I collected this species from under a large stone in the forest in Tsushima Is, Kyushu, Japan. In addition, I considered that the spider recorded as Coelotes sp. by Yaginuma et al. (1976) from Tsushima Is. belongs to Draconarius coreanus. The characteristics of both sexes of this species were described in detail by Kim \& Lee (2007).

\section{References}

Kim, B, W. \& Lee, W. 2007. Spiders of the genus Draconarius (Araneae, Amaurobiidae) from Korea. J. Arachnol., 35; 113-128.

Namkung, J. 2002. The Spiders of Korea. Kyo-Hak Publishing Co., Seoul, 648pp. (In Korean.)

Okumura, K., Shimojana, M., Nishikawa, Y. \& Ono, H. 2009. Coelotidae. pp. 174-205. In: Ono, H. (ed), The Spiders of Japan. Tokai Univ. Press, Kanagawa, XVI+738pp. (In Japanese)

Paik, K. Y., Yaginuma, T. \& Namkung, J. 1969. Results of the speleological survey in South Korea 1966 XIX. Cave-dwelling spiders from the southern part of Korea. Bull. Nat. Sci. Mus., Tokyo, 12: $836^{-843 .}$

Platnick, N. I. 2009. The world spider catalog, version 10.0. American Museum of Natural History, online at http://research.amnh.org/entomology/spiders/catalog/INTRO1.html.

Yamaguchi, T. \& Yaginuma, T. 1971. The fauna of the insular lava caves in west Japan VIII. Araneae (part 2). Bull. Nat. Sci. Mus., Tokyo, 14: 171-180.

Yaginuma, T., Yamaguchi, T. \& Nishikawa, Y. 1976. The Spider Fauna of Tsushima Island. pp. 823-837. In: The Life of Tsushima Island. Nagasaki Biol. Soc., 960pp., 40pls. (In Japanese.)

Yaginuma, T. 1986. Spiders of Japan in Color (New ed.). Hoikusha, Osaka, XXIV+305pp., 64 pls. (In Japanese.)

Wang, X. P. 2002. A generic-level revision of the spider subfamily Coelotinae (Araneae, Amaurobiidae). Bull. Amer. Mus. Nat. Hist., 269: 1-150.

Wang, X. P. 2003. Species revision of the coelotinae spider genera Bifidocoelotes, Coronilla, Draconarius, Femoracoelotes, Leptocoelotes, Longicoelotes, Platocoelotes, Spiricoelotes, Tegecoelotes, and Tonsilla (Araneae: Amaurobiidae). Proc. Calif. Acad. Sci., 54: 499-662.

Received September 3, 2009 / Accepted January 6, 2010 